\title{
The Solar and Lunar Aspects of God Mandulis the Child during the Græco- Roman Period
}

\author{
Marwa Abd EIMeguid ElKady \\ Professor of Archaeology and Civilization of Egypt in Graeco-Roman Period- Faculty of Tourism \\ and Hotels Alexandria University.
}

\section{Sara Elsayed Kitat}

Associate Professor of Egyption Archaeology and Civilization during the Greek, Roman and Byzantine Period- Faculty of Tourism and Hotels Alexandria University.

\section{Nourhan Ramzy Yakout}

Researcher- Tourist Guiding Department

Faculty of Tourism and Hotels, Alexandria University

\section{Abstract}

Mandulis was a local Nubian solar deity, and Lower Nubian region was under his domain. $\mathrm{He}$ was venerated throughout this region, especially at Kalabsha (The ancient town Talmis) where the temple of Kalabsha was built in his honor, in addition to the small temple of Ajûala (Abu Hor). The research deals with the dual function of Mandulis as a solar and lunar deity. This function is revealed through his iconography in the temple of Kalabsha. The decoration of this temple particularly the reliefs of the sanctuary confirms the cyclical aspect of solar and lunar rebirths and the stability of the royal and divine power of god Mandulis. Furthermore, the dual function of Mandulis will be analyzed in the context of the textual evidence, as well as his crowns and attributes. Mandulis became a solar deity through two forms; Mandulis the Elder and Mandulis the Child. The so-called
\end{abstract}

"Vision of Mandulis" threw the light on the solar aspect of Mandulis the Elder. The inscription of a Ptolemaic stela from Ajûala temple describes Mandulis the Child as; "coming forth upon the east as a beautiful prince". In Kalabsha temple, Mandulis the Child was depicted wearing the $\mathrm{HmHm}$ crown and squatting over a lotus flower. On the other hand, and in the same temple, Mandulis is represented in a juvenile lunar form, wearing the full moon, the crescent over a skull-cap and the side-lock of hair like god Khonsu the Child. This iconography of Mandulis is found in three scenes in Kalabsha temple.

Keywords: Mandulis the Child, solar, lunar, Kalabsha, HmHm crown, lotus, crescent. 


\section{Introduction:}

Mandulis ${ }^{1}$ is considered to be a local Nubian solar deity (Erman, 1907: 201; Wilkinson, 2003: 114; Lurker, 2004: 118), and the lower Nubian region was under his domain; as he was venerated throughout this region, especially at Kalabsha (The ancient town Talmis) ${ }^{2}$ (Nock, 1934: 53; Wilkinson, 2003: 114; Hawass, 2004: 15); where the temple of Kalabsha was built in his honor, in addition to the small temple of Ajûala (Blackman, 1911: 80) (Abu Hor). ${ }^{3}$ In ancient Egyptian language the deity's name was pronounced as (Mrwr) or

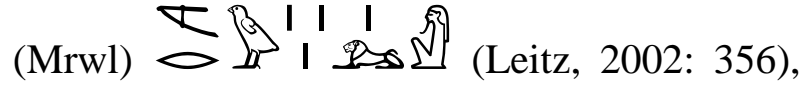

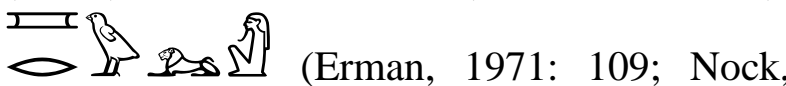
1934: 53; Potter, 2003: 916; Hawass, 2004: 15; Hart, 2005: 90) which was hellenized as Mandulis; as it was found in a text called "the vision of Mandulis" 4 (Hart, 2005: 90-91; ). Moreover, when he adopted the child form his name was written as the following:

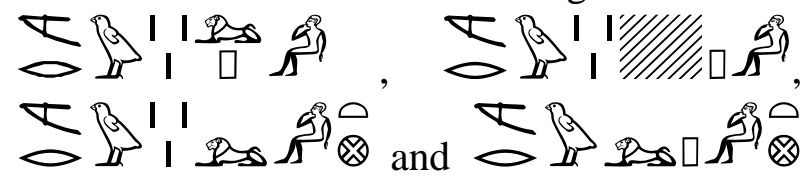
呀

(Leitz, 2002: 356) with the addition to the

1 It is possible that Mandulis was merely a deified man not originally a god. This opinion based on the fact that the hieroglyphic determinative after the sign of his name is a man not a god; (Murray, 2009 : 197).

${ }^{2}$ Talmis is the ancient Roman garrison town -the ancient name of Kalabsha- it lies in Nubia almost on the line of the Tropic of Cancer. Talmis had a great importance where it was the principal town of Dodekaschoinos, moreover, it was the cult center of god Mandulis; (Nock, 1934: 53; Murray, 2009: 197).

3 Ajûala or Abu Hôr is a little temple probably dates back to the Roman Period, nothing remains of this temple today except for a heap of jumbled stones; (Blackman, 1911: 63).

${ }^{4}$ The vision of Mandulis is a Roman text inscribed on the stones of the temple which built in Talmis, moreover, this text recording a brief testimonies of some pagan devotion in honor of god Mandulis. The text can be dated to the third century and written by an anonymous author; Jan-Eric (Steppa, 2005: 115). word pA xrd to his name to become Mrwr pA xrd or Mrwl pA Xrd (Leitz, 2002: 356).

Little is known about his origins but he might have been worshiped during the reign of Thuthmosis III (1479-1425 B.C.E); where the pharaohs of the eighteenth dynasty honored all the Nubians deities including god Mandulis; as rewards for the loyalty of the mercenaries from the same area (Bunson, 2002: 225). It is important to mention that until now the oldest known object attesting the cult of god Mandulis dates back to the reign of Ptolemy VI Philometer (180 - 164 B.C); which is the stela $^{5}$ of Ajûala (Laskowska-Kusztal, 2010: 112).

It is noteworthy to mention that Mandulis was not the progeny of any divine couple; as he was not connected to any family structure; due to his African origins, and his name was not attested in the Egyptian mythology during the Pharaonic Period (Habachi,1969: 174; Laskowska-Kusztal, _ 2010: 113). Nevertheless, Mandulis was occasionally depicted with the divine couple Osiris and Isis in child form replacing god Horus the Child; this depiction suggests that Mandulis in this case could have been a third member of this divine triad. In other scenes, he is represented with goddess Hathor and god Khnum, although none of the texts which accompanying these scenes mention the relations between god Mandulis and the other divine couples, but according to the ornamentation of the so called "Ptolemaic chapel", - located in Kalabsha temple- it seems that in this particular part Mandulis was described as the son of god Khnum (Laskowska-Kusztal, 2010: 118). Meanwhile, according to some scenes from the temple of

${ }^{5}$ This stela was found among the blocks of the ruins temples of Ajûala, it is made of sandstone and only the upper part was discovered. It is dated to the reign of Ptolemy VI Philometor; (Porter \& Moss, 1995: 40). 
Kalabsha, Mandulis the Child was incorporated into Osiris' family; where he is considered to be the son of Osiris and Isis in his form as a man, and the grandson of OsirisApollo and Isis (Markaz Tasj̄̄l al-Āthār alMișrīyah, 1970: 2; Török, 2009: 450; Laskowska-Kusztal, 2010: 118; Török, 2012: 756).

From one hand, Mandulis for the Nubians with Greek culture was considered to be the son of goddess Leto, ${ }^{6}$ on the other hand, they resembled him with the Greek god Apollo ${ }^{7}$ (Török, 2009: 445). As for his worshippers; they were mostly the nomads of the eastern desert, the native Nubians and the Egyptian officials and soldiers who were centered in lower Nubia (Nock, 1934: 53-54; Török, 2009: 451), as well as the Greek and Roman pilgrims (Frankfurter, 2000: 108). In addition, he was also honored by the "Medjay" (Shaw \& Nicholson, 2002: 178) ${ }^{8}$ and the other Nubians who were in the service of Egypt (Bunson, 2002: 225).

Mandulis was worshiped in many forms; one of them is the child form. When he adopted this form, he was depicted as a divine child with the side-lock of hair as a sign of childhood, pointing with his forefinger to his mouth and crowned with the $\mathrm{HmHm}$ illod] Atf or PSxnt y crowns (Nock, 1934: 54;

${ }^{6}$ Leto was a Greek goddess called Latona by the Romans, daughter of the Titan Kois and Phoibe, wife of Zeus and mother of the twins Apollo and Artemis; for more details see: (Lurker, 2004: 111; Daly, 2009: 87).

7 Apollo was a Greek god of sun, hunting and healing - although his origin was probably not Greek but from Asia Minor -, his parents were Zeus and Leto, while his twin sister was Artemis. He was worshiped from circa 1300 B.C to 400 A.D; for more details see: (Lurker, 2004: 16; Jordan, 2004: 25).

${ }^{8}$ The Medjay were a nomadic tribe from the eastern desert of Nubia, who were usually utilized as scouts and infantry since the Second Intermediate Period (1650-1550 B.C); (Shaw \& Nicholson, 2002: 178).
Laskowska-Kusztal, 2010: 112). Occasionally, Mandulis in his child form was depicted wearing the full moon and the crescent over a skull-cap like god Khonsu the Child. Mandulis the Child appears three times with this headdress in the temple of Kalabsha. In this iconography, Mandulis the Child is considered to be a lunar deity (Gauthier, 1911: 21-22; Laskowska-Kusztal, 2010: 112). He is also depicted as a solar child deity as being represented over a lotus flower (Henfling, 1980: 1178).

Through studying the wall reliefs of the Egyptian temples in Upper Egypt dating back from the Graeco Roman period, it is well noted that Mandulis in his different forms was worshipped in Lower Nubia, and his main cult center was at Kalabsha; where he was worshipped along with various other Egyptian divinities. Besides, being venerated at Kalabsha, he also received a cult at Dendur, Philae, Maharraka, and Ajûala. However, Mandulis in his child form was only worshipped at Kalabsha, in addition to Dendur and Ajûala (Nock, 1934: 53; Henfling, 1980: 1177; Wilkinson, 2003: 114).

\section{Mandulis the Child as a Solar Deity:}

Due to the importance of the sun cult throughout the ancient Egyptian history, most of deities during the Graeco-Roman Period adopted titles and representations that linked them to the sun cult. Among these deities is the Nubian god Mandulis the Child. Although little is known about Mandulis' origins, but his nature was certainly solar. Moreover, the decoration of Kalabsha temple especially the reliefs of the sanctuary form an overview of the rituals ensuring the cyclical character of solar and lunar rebirths and the stability of the royal and divine power of god Mandulis. Also his solar nature can be confirmed by the context of some textual evidence from 
Kalabsha and Ajula temples; as it will be explained in the following pages. Furthermore, it is important to mention that the solar and lunar role of god Mandulis the Child identifies him as a protector and guardian of the universal order; in which the ruler adopted the same function and became himself as well the protector of the universal order (LaskowskaKusztal, 2010: 113). However, the deity's solar nature can be revealed through the following points:

\section{1. "Vision of Mandulis":}

According to the late text which is called the "Vision of Mandulis"; god Mandulis was equated with the two Greek gods of the sun, Helios $^{9}$ and Apollo and also linked him at the same time with the Egyptian god Horus (Wilkinson, 2003: 114). In this text it is clear that the writer assimilates god Mandulis with all the solar deities in both Egyptian and Greek worlds; due to the dominant and powerful position of the sun cult in the ancient Egyptian religion which continued during the GraecoRoman Period (Nock, 1934: 75).

The "Vision of Mandulis"; also gives another testimony that god Mandulis was worshipped as a solar deity; where the text mentions the following:

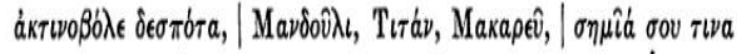

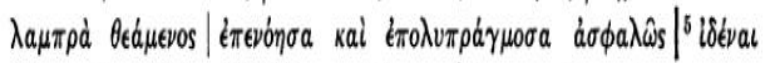

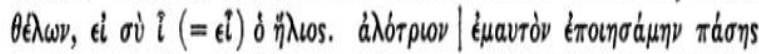

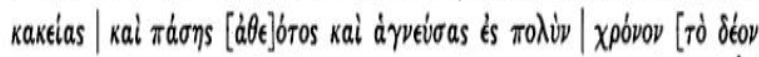

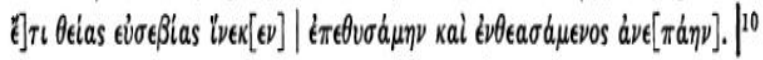

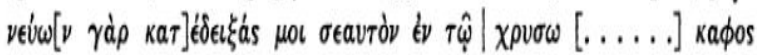

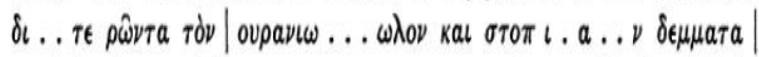

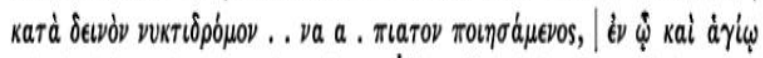

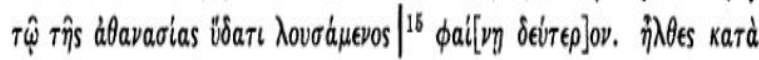

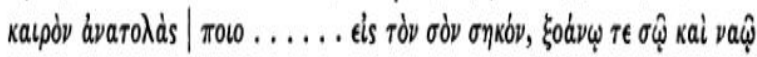

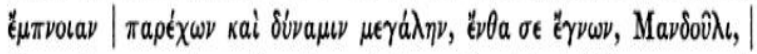

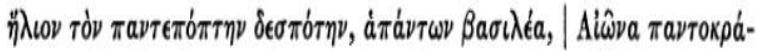

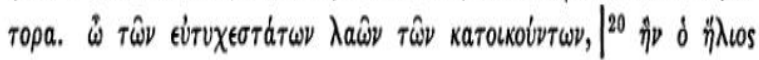

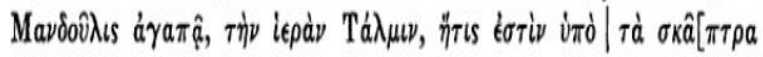

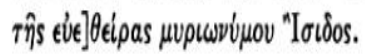

" $O$ rayshooting lord Mandulis, Titan, Makareus, having beheld some radiant signs of thy power I pondered on them and was busied therewith, wishing to know with confidence whether thou art the sun god.......................................Thou

didst come at due season to thy shrine, making thy rising, and giving to thy image and to thy shrine divine breath and great power. Then I knew thee, Mandulis, to be the Sun, the allseeing master, king of all, all-powerful Eternity. O happy folk, that dwell in the city beloved by the Sun Mandulis, even holy Talmis, which is under the scepter of fairtressed Isis of the countless names" (Nock, 1934: 63-64).

The previous text illustrates that the worshipper invokes god Mandulis as god of the sun, but it is important to mention that this invocation here refers to god Mandulis in his general form as it does not specify which image of Mandulis is meant in the text, whether it is Mandulis the Elder or the Child. However, it clearly points out at the solar nature of god Mandulis (Nock, 1934: 58). personification of the sun, he is usually depicted as a charioteer driving the sun across the earth from east to west every day; for more details see: (Sacks, 2005: 147; Daly, 2009: 64). 


\subsection{Stela of Ptolemy VI:}

Mandulis the Child was a solar deity or a sun god in both forms as Mandulis the Elder and Mandulis the Child; as it is clear from the iconographical shape of god Mandulis and the nature of crowns which he adopted, in addition to the accompanying texts. However, this function is well indicated in an inscription on the stela of Ptolemy VI Philometor (180 164 B.C, 163 - 145 B.C) from Ajûala temple, which mentions the follows: "Mandulis the child,..... coming forth upon the east as a beautiful prince (?) of gold beside the place wherein he rises" (Blackman, 1911: 80; (Laskowska-Kusztal, 2010: 112).

\subsection{Hymns from Kalabsha Temple:}

Another indicator to his function as a sun god can be found in the hymns from Kalabsha; where the local worshippers called him in their hymns as: "The god who sends the rays", while other worshippers assimilated him in their hymns with the Greek god of the son Apollo. These hymns were usually written on the walls of the open courtyard of the temples. However, these texts are considered to be a very important testimonies of the deity's solar nature (Hawass, 2004: 15; Tallet, 2012: 412).

\subsection{Temples' Reliefs:}

The solar function of god Mandulis in his Child form is found on two wall scenes from Kalabsha temple; where the deity is depicted in the first scene (Scene. 1) as a solar child deity wearing the $\mathrm{HmHm}$ crown squatting over a lotus flower, while in the second scene (Scene. 2) the deity is represented as a child wearing the composite solar crown (Henfling, 1980: 1178). Following is a description of the two scenes:

\subsubsection{Scene (1) (figs. 1, 2):}

This relief consists of two scenes - the second scene is located beneath an opening - located on the second register of the northern wall of the inner vestibule of Kalabsha temple. The scene shows the Roman Emperor Augustus (27 B.C - 14 A.D) offering the $\mathrm{nXnm}$ vase 6 to god Khnum, goddess Satis and the young god Mandulis; who is represented squatting over a lotus flower (Gauthier, 1911: 109, 110111; Gardiner, 1957: 528 (W. 9); Porter \& Moss, 1995: 17). In this scene, Mandulis is depicted as a naked infant deity squatting over a lotus flower blossomed out of a pond, wearing the $\mathrm{HmHm}$ crown over a long sidelock of hair - which is hanging over his shoulder - and the headband with uraeus adorns it is frontal part. He holds the flail (nxx) $\mathbb{M}_{\text {- one of god Osiris attributes - with }}$ one hand while with the other hand he is gesturing with his finger to his mouth as a sign of childhood (Gauthier, 1911: 111-112).

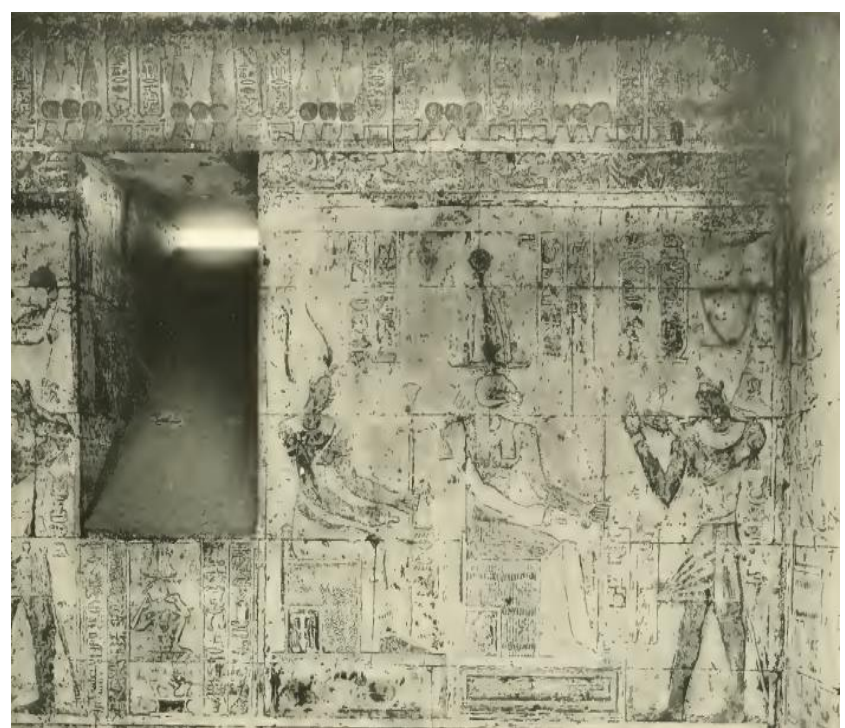

Figure1. Mandulis the Child squatting over a lotus flower, Kalabsha temple. After: (Gauthier, 1911: Pl. XXXVa). 


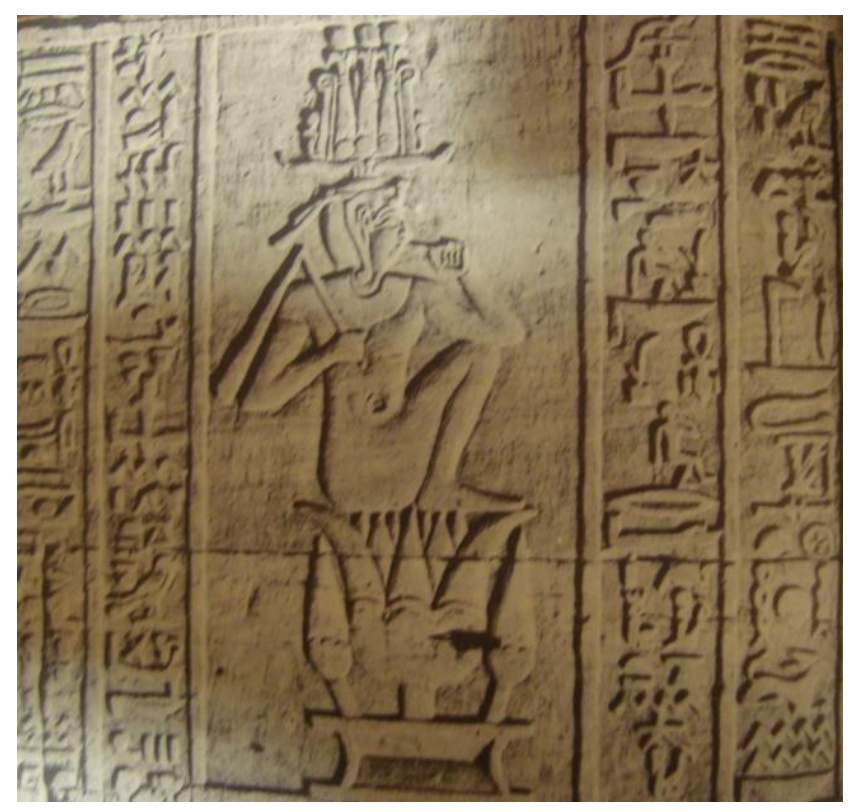

Figure 2. Mandulis the Child squatting over a lotus flower, Kalabsha temple.

After: (Markaz Tasjīl al-Āthār al-Mișrīyah, 1970: p.52).

According to the ancient Egyptian beliefs, the Lotus flower was considered to be a major symbol of rejuvenation and rebirth; from which the young sun god was born. Also according to a spell in chapter 125 of the Book of the Dead, the Lotus flower is symbolizes the daily appearance of the young sun god and referring also to the rebirth of the deceased just like the rebirth of the sun every morning. Thus, the depiction of Mandulis the Child squatting over the Lotus flower indicates his function as a solar deity (Robins, 1993: 188; Dansen, 2016: 28, 43-44).

\subsubsection{Scene (2) (fig. 3):}

Mandulis obviously was sometimes represented with the two forms in one scene, like in this scene. The two forms are usually Mandulis the adult and Mandulis the child standing one behind the other (Blackman, 1911: 80; Nock, 1934: 54), this is referring to the ability of Mandulis the Elder as a sun deity - who represents the sun in it is zenith- who rejuvenates himself into the younger Mandulis the Child (Török, 2009: 450).
This is the first scene of the first register of the eastern wall of the sanctuary of Kalabsha temple. The scene shows the Roman Emperor Augustus (27 B.C - 14 A.D) offering two vases of wine to god Mandulis the Elder and Mandulis the Child (Gauthier, 1911: 38; Porter \& Moss, 1995: 18). In this scene, Mandulis is totally illustrated as a naked child in standing position, with chubby body and protruding belly wearing a short wig, the headband fronted with the uraeus and the side-lock ?; which is surmounted by a crown of ramhorns, sun disk and cobras topped by tall plumes. Meanwhile, he holds the anx sign f in one hand, and the wAs scepter $\{$ in the other (Gauthier, 1911: 38-39).

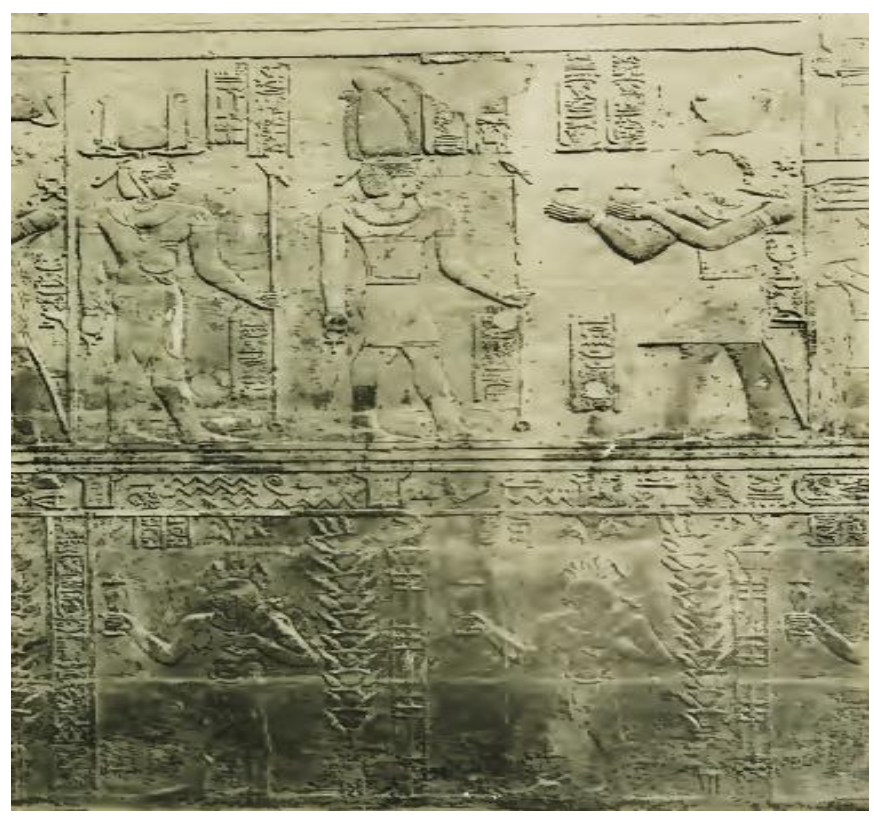

Figure3. Emperor Augustus offering two vases of wine to god Mandulis the Elder and Mandulis the Child, Kalabsha temple. After: (Gauthier, 1911: Pl. XIIIb).

In this scene, god Mandulis is depicted twice as Mandulis the Elder which is being followed by Mandulis the Child, the depiction of the same god twice in the same scene refers to the phases of the sun. Also the depiction of Mandulis the Child wearing a composite 
crown contains the sun disk directly indicates his solar nature. Thus, it become crystal clear that Mandulis the Child is considered to be a solar deity.

\section{Mandulis the Child as a Lunar Deity:}

In addition to the solar nature, Mandulis in his child form was considered to be a lunar deity as well; this function could be emphasized by a wall relief in Kalabsha temple; where Mandulis is represented in an infantile lunar form (fig. 5), wearing the full moon, the crescent over a skull-cap and the side-lock of hair - like god Khonsu the Child - to emphasize his role as a child deity (Gauthier, 1911: 21-22; Laskowska-Kusztal, 2010: 112). It is noteworthy to mention that Mandulis the Child appears three times with this headdress in the temple of Kalabsha (figs. 4, 5, 6). In this iconography, Mandulis the Child is considered to be a lunar deity based on the decorative elements that have showing the lunar aspect of god Mandulis the Child (Gauthier, 1911: 2122; Laskowska-Kusztal, 2010: 112). It is also worthy to mention that Mandulis as a child deity was often represented outside family structure; thus he was emphasizing his cyclical role of solar and lunar rebirth and regenerations; consequently, this concept emphasizes that Mandulis was regarded as a sentinel of the universal order (Budde, 2010; 1; Laskowska-Kusztal, 2010: 113).

The following scenes are considered to be the key scenes that define the lunar role of god Mandulis in his child form (LaskowskaKusztal, 2010: 112 footnote: 10):

\subsection{Scene (3) (fig. 4):}

The first scene is placed on a block found in the foundation debris of the sanctuary of Kalabsha temple. It shows Mandulis the Child standing nude. It is believed that there was a king standing before Mandulis and offering an object which seems to be the symbol of fields (sXt 1.4. h), but now that part of the scene is completely erased (Gauthier, 1911a: 345). In this scene, Mandulis is completely represented as a naked child in standing position. Moreover, he is depicted putting his finger at his mouth, while wearing the lunar disk and the crescent (the lunar crown) over a short wig, which emphasized his role as a lunar deity. In addition, he wears the side-lock of hair 6; which is hanging behind his ear and the headband which adorned with the uraeus at it is front part. Finally, a necklace in the shape of the heart amulet is is suspended from his neck (Gauthier, 1911a: 345).

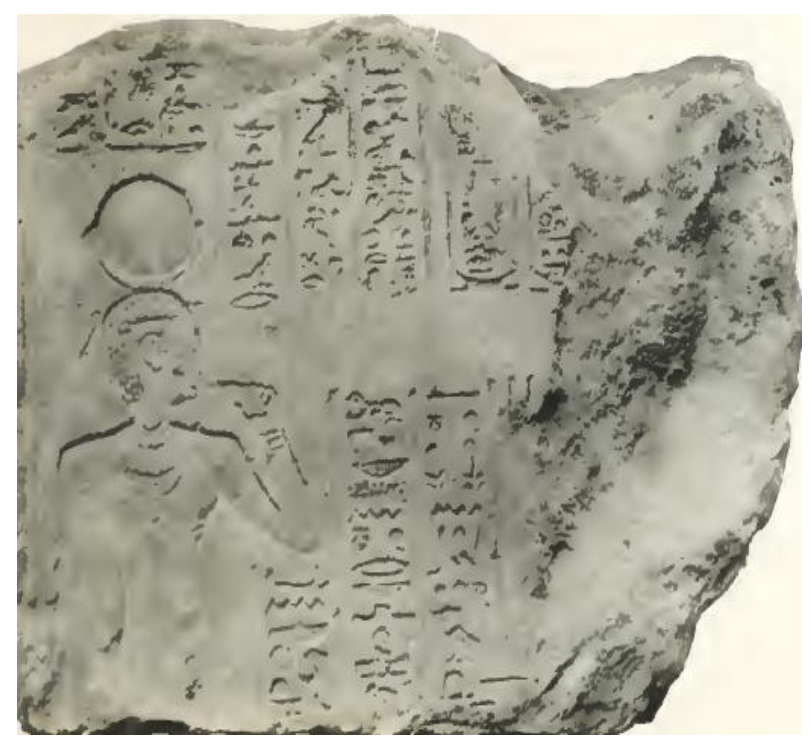

Figure 4. Mandulis the Child wearing the lunar crown, block from the foundation of the sanctuary of Kalabsha temple.

After: (Gauthier, 1911a: Pl. CXVIIC).

\subsection{Scene (4) (fig. 5):}

The second scene of the series of scenes that reflect the lunar nature of god Mandulis the Child is located on the first register - second scene - of the south wall of the sanctuary of the temple of Kalabsha. The scene shows the 
Roman Emperor Augustus (27 B.C - 14 A.D) in adoration pose in front of the young god Mandulis, goddess Nekhbet (?) and goddess Wadjet (Gauthier, 1911: 19, 21; Porter \& Moss, 1995: 18). In this scene, god Mandulis is represented as an adolescent deity, half naked only wears a short kilt attached to it is rear part the ceremonial tail. As for his headdress he is wearing the crescent and the full moon over the skull-cap and the long sidelock which is hangs over his shoulder. Finally, he holds the wAs scepter $\mathfrak{h}$ and anx sign f each one in a separated hand (Gauthier, 1911: 21-22; Leitz, 2002: 356).

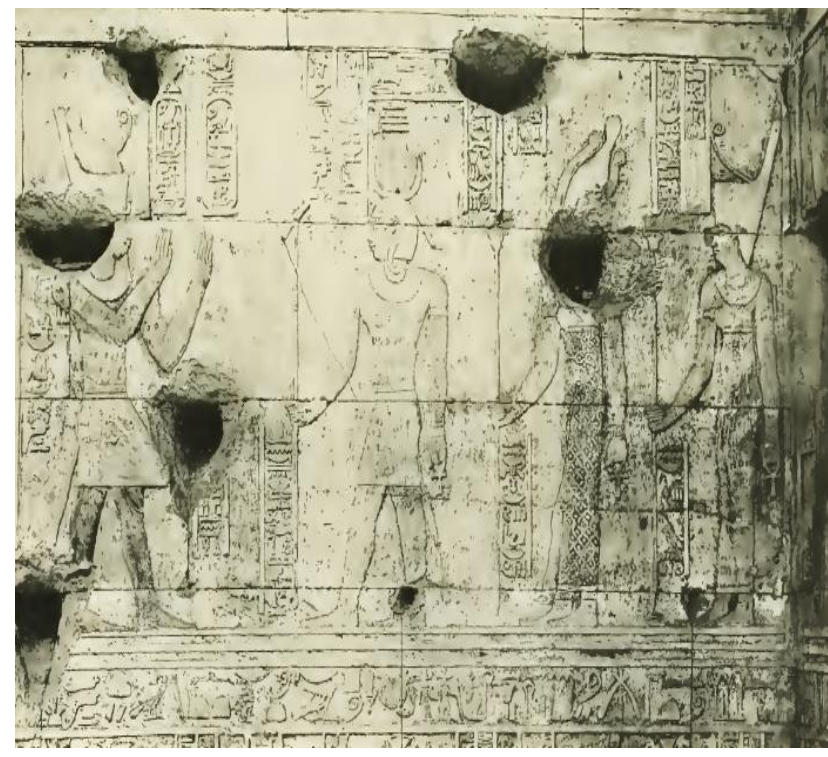

Figure 5. Mandulis wearing the lunar crown, Kalabsha temple.

After: (Gauthier, 1911: P1.VIIb).

\subsection{Scene (5) (fig. 6):}

The last scene of the series of scenes that prove the god's lunar nature is placed on the second register - third scene - of the northern wall of the Ptolemaic chapel at the temple of Kalabsha. The scene shows the king (probably Ptolemy IX Soter II or Ptolemy V Epiphanes) offering a vase to god Mandulis (Gauthier, 1911a: 327; Porter \& Moss, 1995: 20). In this scene, Mandulis is depicted as a seated child deity putting his finger on his mouth as a sign of childhood, while holding the anx sign with the other hand. As for his headgear, he is represented wearing the lunar disk and the crescent over a skull-cap adorned with the uraeus at the forehead (Gauthier, 1911a: 327).

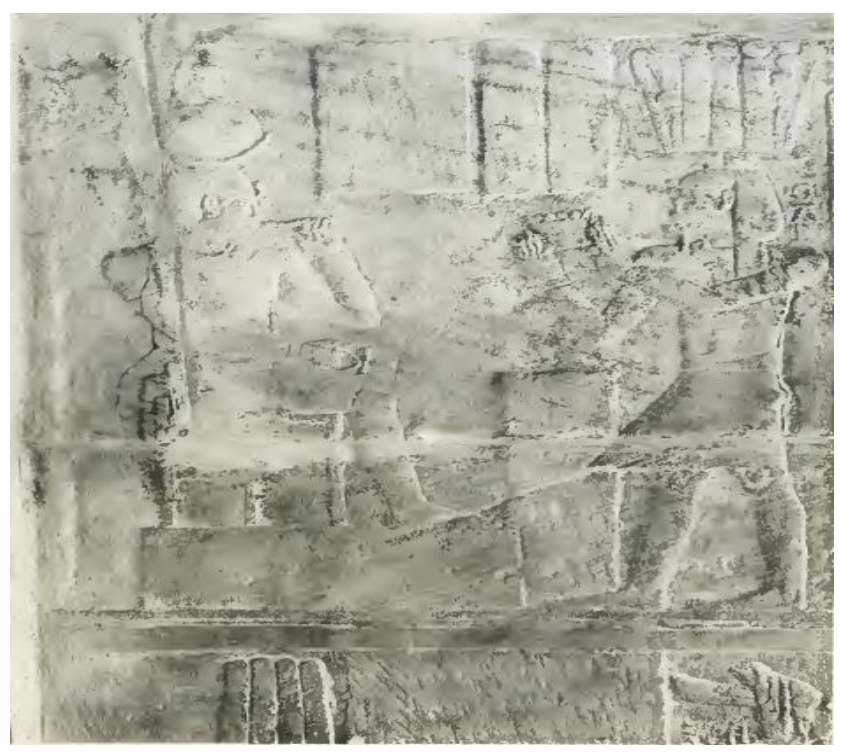

Figure 6. King offering a vase to god Mandulis the Child, Kalabsha temple.

After: (Gauthier, 1911a: Pl. CXIIb).

In the previous three scenes, god Mandulis the Child is represented wearing the lunar crown, which is originally worn by god Khonsu (the moon god) referring to his lunar nature. Moreover, he also wears the lunar crescent (which is part of the lunar crown, that consists of the lunar disk and the lunar crescent) which is according to the ancient Egyptian beliefs was considered to be the boat of safety from the primeval waters (Nun) for the young child and the place for him to be reborn again from the virgin lunar mother; thus, by adopting Khonsu's crown (the lunar crown) Mandulis was definitely considered to be a lunar deity (Massey, 2007: 438). 


\section{Conclusion:}

After studying this topic and examining the different scenes and texts that recording the dual function of god Mandulis the Child during the Graeco-Roman Period; the following points can be concluded:

4.1. Although it was believed that the cult of Mandulis dates back to the reign of Thuthmosis III (1479 - 1425 B.C), who was known to honor all the Nubian deities during his reign, but the oldest known object of the god is the stela of Ajûala which dates back to the reign of Ptolemy VI Philometer (180 - 145 B.C).

4.2. Although Mandulis was worshipped throughout Lower Nubia but he was only venerated at Kalabsha, in addition to Dendur and Ajûala in his child form.

4.3. Moreover, as a god with solar and lunar aspects, Mandulis was represented in many forms; firstly as a child deity wearing the $\mathrm{HmHm}$, lunar and the solar composite crowns, secondly as an adolescent deity with childish features wearing the lunar crown.

4.4.It is apparent that Mandulis the Child was considered to be a solar deity; which is proved by the following points:

4.4.1 In (Fig. 2) Mandulis the Child is depicted squatting over a Lotus flower $\oslash$; which in turn was an important element in ancient Egyptian religion; as it resembles the great goddess who gave birth to the sun. Also the blue Lotus was a general symbol of rebirth in ancient Egyptian beliefs. In addition to that, and according to Pinch, (2002) 'In some versions of the Egyptian creation myth, the sun god was born from a blue Lotus flower that emerged from the primeval water'; thus the Lotus flower is directly referring to the sun (Pinch, 2002: 158). Consequently, in this case Mandulis the Child according to his depiction in (Fig. 2)is considered the young sun god who was born from the Lotus flower that blossomed out of the pond (the pond refers to the primeval water).

4.4.2 Moreover, in the same scene (Fig. 2) the deity is depicted wearing the

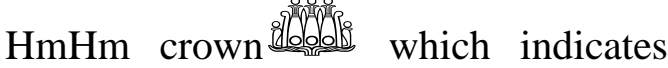
the role of child deities in cyclical rejuvenation, renewal as well as rebirth. Furthermore, the HmHm crown also refers to the powerful solar nature of the child deities and their roles as guarantors of food and rejuvenation (Yakout, 2017: 249).

4.4.3 In (Fig. 3) the deity is wearing a composite crown which consists of the sun disk flanked by two tall plumes, ram-horns and cobras. This solar crown refers to the solar nature of god Mandulis. Though, based on what mentioned before, it is clear that Mandulis the Child is considered to be a solar deity.

4.5.The lunar nature of god Mandulis the Child can be emphasized by three scenes from the temple of Kalabsha; where Mandulis is represented in a juvenile lunar form wearing the lunar crown. However,

the lunar crown $\Theta$, which was usually worn by god Khonsu the Child and occasionally worn by Mandulis the Child refers to the lunar character of these deities. 
4.6. Moreover, it is important to mention that the dual Function (solar and lunar natures) of god Mandulis the Child identifies him as a protector of the universal order.

4.7.After surveying the different scenes of Mandulis dating back to the Graeco Roman period, it is clear that Mandulis the Child was only depicted three times with attributes (the lunar crown) referring to his lunar nature on the wall reliefs of Kalabsha temple and only depicted in two scenes with explicit attributes (the lotus flower, the $\mathrm{HmHm}$ and solar crowns) indicating his role as a solar deity also in Kalabsha temple.

\section{Bibliography}

1. Blackman, A. M. (1911), TIM: The Temple of Dendûr , Le Caire: Imprimerie de L'Institut Français D'archéologie Orientale.

2. Budde, D. (2010), "Child Deities", In J Dieleman \& W. Wendrich (eds.), UCLA Encyclopedia of Egyptology, Los Angeles: University of California.

3. Bunson, M. R. (2002), Encyclopedia of Ancient Egypt, (Revised edition), New York: Facts on File.

4. Daly, K. N. (2009), Greek and Roman Mythology, A to Z, ( $3^{\text {rd }}$ edition), New York: Infobase Publishing.

5. Dansen, I. (2016), Why are we here Grandfather: An Analyses of the Connetion(s) between the Sons of Horus and the Symbols and Gods Represented in the Shrine Detail of Chapter 125 of the Book of the Dead, Leiden: Leiden University.

6. Erman, A. (1907), A Handbook of Egyptian Religion, translated by: A.S. Griffith, London: Archibald Constable and Co. Ltd.

7. Erman, A. (1971), Wörterbuch der Ägyptischen Sprache, II, Berlin: Akademie Verlag.

8. Frankfurter, D. (2000), Religion in Roman Egypt: Assimilation and Resistance, New Jersey: Princeton University Press.
9. Gardiner, A. H. (1957), Egyptian Grammar: Being an Introduction to the Study of Hieroglyphs, ( $3^{\text {rd }}$ edition) Oxford: Publication of the Griffith Institute.

10. Gauthier, H. (1911), TIM: Le Temple de Kalabchah, Vol. I, Le Caire: Imprimerie de I'Institut Français D'archéologie Orientale.

11. Gauthier, H. (1911a), TIM: Le Temple de Kalabchah, Vol. II, Le Caire: Imprimerie de I'Institut Français D'archéologie Orientale.

12. Hart, G. (2005), The Routledge Dictionary of Egyptian Gods and Goddesses, (2 ${ }^{\text {nd }}$ edition), London and New York: Routledge.

13. Hawass, Z. (2004), The Island of Kalabsha, Cairo: American University in Cairo Press.

14. Henfling, E. (1980), "Mandulis", in LÄ III, Wiesbaden: Otto Harrassowitz, cols. 11771179.

15. Habachi, L. (1969), "Divinities Adored in the Area of Kalabsha, with a Special Reference to the Goddess Miket", Mitteilungen des Deutschen Archäologischen Institutes Abteilung Kairo, Band 24, Wiesbaden: Otto Harrassowitz, pp.169-183.

16. Jordan, M. (2004), Dictionary of Gods and Goddesses, ( $2^{\text {nd }}$ edition), New York: Facts on File Publications.

17. Laskowska-Kusztal, E. (2010), "Relations between the Cult Center of Mandulis at Kalabsha and the Religious Centers on Elephantine and Philae," In M. Dolińska et al (eds.), $\quad$ Agyptologische Tempeltagung: Interconnections Between Temples, Vol. 8, (pp.111- 122), Weisbaden: Harrassowitz Verlag.

18. Leitz, C. (2002), Lexikon der ägyptischen Götter und Götterbezeichnungen: p-nbw, Band III, OLA 112, Leuven: Peeters Publishers.

19. Lurker, M. (2004), The Routledge Dictionary of Gods, Goddesses, Devils and Demons London: Routledge and Kegan Paul.

20. Markaz Tasjīl al-Āthār al-Mișrīyah, (1970), Kalabsha, Centre de Documentation sur l'Ancienne Egypte, Le Caire.

21. Massey, G. (2007), Ancient Egypt: The Light of the World, New York: Cosimo, Inc.

22. Murray, M. A. (2009), Egyptian Temples, New York: Routledge. 
23. Nock, A. D. (1934), “A Vision of Mandulis Aion," HTR, vol. 27, no.1, pp. 53-104.

24. Pinch, G. (2002), Handbook of Egyptian Mythology, California: ABC-CLIO.

25. Porter, B. \& Moss, R. (1995), Topographical Bibliography of Ancient Egyptian Hieroglyphic Texts, Reliefs and Paintings: Nubia, the Deserts and Outside Egypt, Vol. VII, Oxford: Griffith Institute.

26. Potter, D. S. (2003), "Mandulis" In S. Hornblower et al, (eds.), The Oxford Classical Dictionary, ( $3^{\text {rd }}$ edition), New York: Oxford University Press.

27. Robins, G. (2003), Women in Ancient Egypt, Massachusetts: Harvard University Press.

28. Sacks, D. (2005), Encyclopedia of the Ancient Greek World, (Revised Edition), New York: Facts on File, Inc.

29. Shaw, I. \& Nicholson, P. (2002), The British Museum Dictionary of Ancient Egypt, Cairo: The American University in Cairo Press.

30. Steppa, J-E. (2005), John Rufus and The World Vision of Anti-Chalcedonian Culture, $\left(2^{\text {nd }}\right.$ Revised edition), New Jersey: Gorgias Press LLC.

31. Tallet, G. (2012), “Oracles” In C. Riggs (ed.), The Oxford Handbook of Roman Egypt, Christina Riggs (ed.), ( $1^{\text {st }}$ edition), Great Britain: Oxford University Press.

32. Török, L. (2009), Between Two Worlds: The Frontier Region between Ancient Nubia and Egypt 3700 BC-500 AD, Netherlands: Brill NV.

33. Török, L. (2012), "Between Egypt and Meroitic Nubia: The Southern Frontier Region" In C. Riggs (ed.), The Oxford Handbook of Roman Egypt, ( $1^{\text {st }}$ edition), United Kingdom: Oxford University Press.

34. Wilkinson, R. H. (2003), The Complete Gods and Goddesses of Ancient Egypt, London: Thames and Hudson.

35. Yakout, N. R. (2017), Iconography of Divinities Represented in Child Form in Egyptian Temples during the Graco-Roman Period, (Unpublished Master Thesis), Alexandria University Alexandria, . 